\title{
Credit Supply and Business Investment During the Great Recession: Evidence from Public Records of Equipment Financing
}

\author{
Jesse Edgerton* \\ Federal Reserve Board
}

November 26, 2012

\begin{abstract}
It is often asserted that the financial crisis of 2008 caused a recession in the real economy by restricting the supply of credit to firms and households, but this view has been questioned by a number of researchers. This paper uses novel data on lending relationships from Uniform Commercial Code filings of loans secured by business equipment to measure how lender distress affected firm-level investment outcomes after the crisis. In specifications that compare firms in the same county-industry-size cell, I find that firms that were dependent on lenders that experienced the most distress during the crisis financed significantly less equipment than average firms after the crisis, despite a considerable amount of substitution toward non-distressed lenders. Variation across lenders can account for a 17\% decline in aggregate equipment financing, or about onethird of the total decline in financing in the sample of small businesses used in the paper.
\end{abstract}

JEL Codes: G31, G21.

Keywords: Financial crisis, credit supply, bank lending, capital expenditures, equipment financing.

*Email: jesse.edgerton@gmail.com. Any views expressed here are those of the author only and need not represent the views of the Federal Reserve Board, its staff, or any other institution. I thank Glenn Hubbard, Atif Mian, Karen Pence, Jonathan Rose, Stacey Tevlin, and seminar participants at the Brookings Institution, the University of Rochester, the Federal Reserve Board, and the NBER Summer Institute for helpful comments. I thank Karuna Batcha for excellent research assistance. 


\section{Motivation}

From the second quarter of 2008 to the second quarter of 2009, real spending on nonresidential equipment and software in the United States fell by more than 20 percent, and gross domestic product fell by 5 percent. It is often asserted that these declines in real investment and output were caused by a contraction in the supply of lending due to disruptions in the financial sector that began in the summer of 2007 and developed into a severe crisis in late 2008. ${ }^{1}$ Consistent with this view, much of policymakers' response to the crisis was driven by the notion that fixing disruptions in the financial system could prevent or mitigate declines in real activity. ${ }^{2}$

Others have suggested, however, that declines in real investment were caused not by disruptions to the supply of credit, but by declines in demand for investment driven by factors like uncertainty shocks (Bloom, Floetotto, and Jaimovich [2009]), self-fulfulling bad equilibria (Farmer [2011]), distortions in the market for labor (Mulligan [2010]), or aggregate demand shortfalls caused by household balance sheet deterioration (Mian and Sufi [2012]). If these other factors were responsible for declines in real activity, it is unclear if policymakers' emphasis on supporting financial institutions during the crisis was optimal. Indeed, debates over the wisdom of "bailouts" during the crisis remain quite heated.

This paper uses a newly-created dataset from Uniform Commercial Code (UCC) filings of loans secured by business equipment to provide new evidence on the importance of credit supply in driving declines in business investment during the recession. The UCC governs the operation of a collateral registry system that allows lenders in the United States to provide

\footnotetext{
${ }^{1}$ For example, Robert Hall wrote in the Journal of Economic Perspectives, "A large decrease in the values of the asset holdings of financial institutions resulted in a dramatic intensification of agency problems in those institutions and to a lesser extent in nonfinancial companies. Credit spreads widened and credit rationing became widespread. The diminished ability to finance the acquisition of capital goods resulted in huge cutbacks of all types of investment - plant, equipment, inventories, residential construction, and consumer durables purchases - while other categories of GDP remained roughly constant." (Hall [2010]), emphasis added)

${ }^{2}$ Examples include TARP bank equity purchases, Public-Private Investment Partnership, Money Market Investor Funding Facility (MMIFF), Asset-Backed Commercial Paper Money Market Mutual Fund Liquidity Facility (AMLF), Commercial Paper Funding Facility (CPFF), Primary Dealer Credit Facility (PDCF), Term Securities Lending Facility (TSLF), etc.
} 
public notice of their secured claims in borrowers' collateral. Data from this system provide a link between lenders and borrowers and thus permit me to provide cross-sectional evidence on lender distress and firm investment during the crisis.

Such cross-sectional information is essential for separating the effects of credit supply disruptions from other factors that could also drive the coincident declines in lending and investment observed in aggregate time-series data. Further, the data provide information primarily on small businesses, which are often claimed to have been particularly affected by recent contractions in credit supply, but are little-studied due to data limitations. The data also prominently feature non-bank lenders like finance companies, who are similarly understudied.

To my knowledge, this is the first paper to use data from UCC filings for research. An important contribution of the paper is to bring the UCC filing system to the attention of researchers, both as a source of data on lending and investment and as a potential subject of study in its own right. Data from UCC filings could inform a wide variety of questions where information on lender and borrower identities and geographic locations would be useful. Future research could also study whether and how the UCC filing system facilitates lending and capital formation, with the aim of improving the effectiveness of the system.

In this paper, using UCC data from California in specifications that compare firms within county-industry-size cells, I find that firms that were fully dependent before the crisis on lenders that experienced the most distress during the crisis financed about $30 \%$ less equipment after the crisis than did the average firm that had no pre-crisis relationship with these distressed lenders. ${ }^{3}$ Further results show that firms dependent on lenders that became distressed were able to shift a considerable amount of their financing to alternative, non-distressed lenders, particularly to the captive finance companies of equipment manufacturers. However, this substitution to alternative lenders was not enough to fully overcome

\footnotetext{
${ }^{3}$ The lenders I identify as "most distressed" for this purpose are failed or "problem" banks, finance companies that entered bankruptcy, and Citigroup (which regulators debated downgrading to a problem bank, but did not).
} 
the decline in financing from the distressed lenders.

To assess the implications of these estimates for the impact of credit supply contractions on aggregate investment, I perform a simple counterfactual simulation. I use the estimated coefficients from baseline specifications to simulate aggregate equipment financing in this sample under the counterfactual assumption that all firms borrowed exclusively from certain large lenders that appear to be among the "least distressed" in the data-John Deere, Caterpillar, and Wells Fargo. This exercise reveals that variation across preperiod lenders can explain about a $17 \%$ decline in total machines financed in the postcrisis period, relative to a counterfactual where all firms financed equipment through these least-distressed lenders. This $17 \%$ decline accounts for roughly one third of the total decline in financing seen in the sample. Overall, results thus suggest that variation across lenders (which I interpret as variation in the supply of credit) can explain a substantial drop in aggregate investment in this sample. Nonetheless, other factors must also be at work to explain the entire decline.

These results are subject to two important caveats. First, results rely on measures of investment that can be constructed from UCC filings. I observe, for example, that firms that financed equipment from banks that failed during the crisis appear less often as equipment purchasers in UCC filings after the crisis. However, I cannot be certain that these firms were not acquiring equipment through other means that do not result in a UCC filing, such as cash purchases. One could argue in response that the small firms using collateralized financing that appear on UCC filings were likely already near the end of their "pecking order" of financing options. That is, if they were able to fund equipment purchases with cash, they would have already been doing so. Further, when compared to previous literature focused on lending outcomes at the bank level following shocks to banks, the UCC data allow me to extend analysis to investment outcomes at the firm level for a set of firms that have never been studied in this context before. Even if the data do not provide an exhaustive view of investment by these firms, this is still an important step forward.

Second, as in all extant studies of the financial crisis, there is no truly exogenous source 
of variation across lenders in the extent to which their assets lost value or their lending was otherwise curtailed during the crisis. All such variation is driven by prior choices made by the lenders, which could be correlated with characteristics of their borrowers.

I take two empirical approaches to this identification problem. First, I focus on specifications including detailed sets of fixed effects and interactions so that results rest on comparisons within county-industry-size cells across firms that relied on different lenders. That is, results do not rest on comparing firms in California to firms in North Dakota or on comparing construction companies to farms. Instead, they rely on comparisons among firms in the same county, in the same industry, and of about the same size that borrowed from different lenders before the crisis.

Still, one can never be certain that firms borrowing from lenders that became distressed during the crisis were not different in some unobservable way from firms in the same countyindustry-size cell that were borrowing from other lenders. Thus, I also investigate firms' substitution towards lenders that did not become distressed. I find that firms that had depended on lenders that became distressed increased their borrowing from nondistressed lenders relative to comparable firms, where one would have expected them to decrease their borrowing from these other lenders if their decline in overall borrowing were driven by unobserved firm characteristics rather than lender distress. ${ }^{4}$ Thus, there is a compelling argument that the relationship between lender distress and firm investment documented here is indeed causal.

The next section of the paper provides a more detailed review of related literature. Section 3 provides an overview of the UCC filing system and discusses the data used in the paper. Section 4 discusses the paper's empirical strategy and its shortcomings in more detail. Section 5 presents results and Section 6 concludes.

\footnotetext{
${ }^{4}$ This argument for identification is essentially the same as that in widely-cited work by Khwaja and Mian [2008] using linked lender-firm data from Pakistan to study a different episode.
} 


\section{Review of related literature}

This paper relates to the long literatures on the impact of financing constraints on firm investment (Fazzari, Hubbard, and Petersen [1988], Kaplan and Zingales [1997]) and on the bank lending channel of monetary policy (Bernanke and Blinder [1988], Kashyap, Stein, and Wilcox [1993]), but I focus this literature review on a subset of these papers most relevant to the issue at hand - the impact of lender distress on firm investment in the United States during the recent financial crisis and recession. As interest in this area has grown rapidly in the wake of the financial crisis, I attempt to present a thorough review. Readers uninterested in a lengthy literature review may skip to section 3, beginning on page 10 .

\subsection{Effects of bank credit supply}

There are a number of papers that find evidence of an impact of bank credit supply on firm-level outcomes in other contexts. For example, Slovin, Sushka, and Polonchek [1993] use information gathered from news media reports to identify 54 firms that borrowed from Continental Illinois before its failure in 1984, and Chava and Purnanandam [2011] use linked bank-firm data from Dealscan to study the impact of the 1998 Russian debt crisis on firms that borrowed from banks affected by the crisis. Both papers find evidence that borrowers from these banks experienced abnormal negative stock returns around the relevant events, although they do not report any direct evidence of effects on capital expenditures or other forms of investment. Similarly, Hubbard, Kuttner, and Palia [2002] find that firms borrowing from less well-capitalized banks face higher borrowing costs after controlling for observable firm characteristics, suggesting that firms do face some cost of switching banks if their original bank becomes distressed.

Khwaja and Mian [2008] use national lending registry data that links banks and firms in Pakistan. They find that shocks to bank liquidity following unanticipated nuclear tests in Pakistan led to significant decreases in lending by affected banks. These lending declines 
led to decreases in firm-level borrowing at firms that depended on these banks, but only among the smaller firms in their data. Gan [2007] performs a similar exercise using data from the Japanese banking crisis of the early 1990s. Schnabl [2012] finds that international banks exposed to the 1998 Russian crisis reduced their lending to Peruvian banks, which resulted in less lending to Peruvian firms. Paravisini [2008] exploits formula-based allocation of government funding across Argentine banks and finds that the exogenous component of bank funding does lead to increases in total debt at the firm level.

A few papers have even established links between bank credit and measures of aggregate real activity at the state or county level. Peek and Rosengren [2000] find that US states that expericenced larger declines in commercial real estate lending by Japanese banks during the Japanese banking crisis also experienced larger declines in construction activity. Ashcraft [2005] finds that failures of healthy banks (induced by the failure of other banks owned by the same holding company) led to notable declines in county-level income measures in a sample of Texas counties.

Although these papers have shown that the supply of bank credit was important for real activity in certain times and places, others have found the opposite result in other contexts. Notably, Driscoll [2004] and Ashcraft [2006] argue that variation in the aggregate supply of bank lending induced by U.S. monetary policy has had insignificant effects on real activity at the state level. This paper provides new evidence on the importance of the contraction in credit supply for real investment in the United States during the recent financial crisis and recession, an episode deserving of study in its own right.

\subsection{Effects of the 2007-2009 financial crisis on credit supply and real activity}

Of course, a rapidly growing literature has also begun investigating the role of credit supply during the recent crisis and recession. Several papers have found larger declines in lending among particular groups of more-distressed banks. Ivashina and Scharfstein [2010] find that 
banks with more deposit financing cut their syndicated lending less than other banks, and that banks that had co-syndicated loans with Lehman brothers reduced their lending more (likely as a result of credit-line drawdowns). Rice and Rose [2010] find notably larger lending decreases among banks that were more exposed to GSE preferred stocks, which they argue were essentially exogenously distributed across banks and which lost most of their value unexpectedly when the GSEs were placed into conservatorship in September 2008. Carlson, Shan, and Warusawitharana [2011] estimate effects of bank capital ratios on bank lending by comparing banks with sets of other banks matched on location, size, and balance sheet characteristics. They find that banks with lower capital ratios had lower lending growth, particularly during the crisis period. Ramcharan, den Heuvel, and Verani [2012] find that declines in the value of asset-backed securities on the balance sheets of large "corporate credit unions" led to declines in lending among their smaller member "natural person credit unions." Although these papers document variation in lending declines at the lender level, they cannot speak to the question of whether firms that relied on these lenders were able to substitute to other lenders (including non-banks, like finance companies). ${ }^{5}$

There are, however, also a handful of papers that have focused on firm-level data. Duchin, Ozbas, and Sensoy [2010] find that Compustat firms with larger cash reserves experienced smaller declines in investment spending during what they call the "early crisis" from July 2007 to June 2008 suggesting that there was a decline in the availability of external finance during this period. However, they find less evidence of a further contraction in external finance during the "deep crisis" period in late 2008 and early 2009, when the largest investment declines occurred. Kahle and Stulz [2010] find that Compustat firms' financial policies during the crisis are largely inconsistent with the notion that a contraction in bank credit supply drove the decline in business investment. Namely, rather than funding investment by replacing bank lending with equity issuance or spending out of cash holdings, firms hoarded

\footnotetext{
${ }^{5}$ In fact, Ivashina and Scharfstein [2010] conclude their paper by noting that "The ability to switch lenders may be critical to mitigating the effects of a reduction in the supply of credit... Whether this has been a problem in the current financial crisis is an open question and deserves further inquiry."
} 
cash and reduced their equity issuance.

A few papers have also studied linked lender-firm data from other countries where such data are more widely available. Iyer, Lopes, Peydro, and Schoar [2010] study matched firmbank data from Portugal during the recent crisis period. They focus on bank reliance on the interbank lending market, and find larger declines in total bank borrowing among firms that borrowed more heavily from banks that relied heavily on the interbank lending market. Puri, Rocholl, and Steffen [2011] perform a similar exercise, relating data on consumer loans by German savings banks to the banks' U.S. subprime exposure. Paravisini, Rappoport, Schnabl, and Wolfenzon [2011] use linked bank-firm data on Peruvian exporters and find that exports by Peruvian firms that were dependent on US-exposed banks were lower than exports by other firms, such that credit shortages can explain $15 \%$ of the decline in Peruvian exports during the crisis. Although these three papers provide evidence that a contraction in credit supply was important in transmitting the crisis and recession from the U.S. to other countries, they cannot speak directly to the question of whether credit supply caused the U.S. recession, which is my focus in this paper. Finally, two papers that have circulated contemporaneously with this one have used linked lender-firm data from the Dealscan database of syndicated loans to study similar issues (Carvalho, Ferreira, and Matos [2012], Chodorow-Reich [2012]).

Given this rapidly-expanding literature, it is worth reiterating the contributions of this paper relative to those that are already circulating. This paper is among the first to use linked lender-firm data from the United States to study the recent financial crisis and recession. To this end, this paper uses a newly-created dataset on lending relationships from the UCC filing system for secured loans. The UCC system is an important piece of the plumbing of lending and investment in the United States (particularly for small businesses), but thus far it has almost entirely evaded the attention of researchers in economics and finance. ${ }^{6}$

\footnotetext{
${ }^{6}$ There is a literature focusing on the importance of credit and collateral registries in facilitating lending and investment around the world (Pagano and Jappelli [1993], Jappelli and Pagano [2000], Galindo and Miller [2001], Love and Mylenko [2003], Kallberg and Udell [2003], Djankov, McLiesh, and Shleifer [2007], de Janvry, McIntosh, and Sadoulet [2010], Cheng and Degryse [2010], Haselmann, Pistor, and Vig [2010], Hertzberg, Liberti, and Paravisini [2011]). Nonetheless, I believe this paper is the first to make use of data from Uniform Commercial Code filings, the public collateral registry system for personal property in the
} 


\section{Data}

The paper's insights come from combining two types of data-public records of secured loans filed under the Uniform Commercial Code, and information on banks and other lenders that became distressed during the crisis.

\subsection{UCC Filings}

\subsubsection{Background on the UCC filing system}

The Uniform Commercial Code is a set of laws governing commercial transactions like sales, leases, and rentals. In the United States, these kinds of laws are made at the state level. Since the 1940s, however, the states have coordinated through a body known as the National Conference of Commissioners on Uniform State Laws to make these laws uniform across states. This uniformity allows firms to avoid needless confusion and expense when conducting similar activities in different states. See Stone and Adams [2008] for more on the Uniform Commercial Code.

Article 9 of the UCC governs transactions that create a "security interest" in "personal property and fixtures." Transactions governed by the article thus exclude any transactions involving real estate, which are governed by other laws. The UCC may also be superseded for personal property governed by title laws, such as airplanes and automobiles. Article 9 is relevant for transactions where a party takes a secured interest in property like equipment, inventories, bank accounts, receivables, etc.

As is widely known, by taking a security interest in a particular piece of property, the secured party has priority over any unsecured creditors in receiving any proceeds from the property in the event that the debtor defaults. Less well-known is the legal mechanism through which a secured parties can stake his claim to a particular piece of property. A security interest can be "perfected" (as this claim-staking is known) by filing a financing United States. 
statement under Article 9 of the UCC.

Each of the United States has an office that processes UCC financing statements and makes them available for searching by debtor name. These databases serve to provide public notice to other potential creditors of existing claims on debtors' assets. Typically, if two creditors both make claim to the same piece of a debtor's property, the creditor that filed his UCC statement first has priority in bankruptcy. Secured parties are not legally required to file a statement, but it is in their interest to file if they want their claim to be respected in the event of default.

Following page 11 of this paper is an example UCC filing from the state of North Carolina. This filing and thousands more can be freely downloaded from http://www.secretary.state.nc.us/ucc/FilingSearch.aspx. Note that the statement simply provides the date of the filing, the names and addresses of the debtor and the secured party, and a description of the property in which a security interest is taken - that is, the collateral. In this case, Leary Brothers Logging, Inc. is the debtor (Rachel Leary has also signed as an additional debtor), and Deere and Company (maker of John Deere equipment) is the secured party. The collateral statement names a John Deere 2520 Compact Utility Tractor with serial number 208130 and a Bush Hog TH60 mower attachment with serial number 08093, and it includes some boilerplate language covering any improvements upon or proceeds from this equipment.

Note, however, the many pieces of information about the transaction that are not included on the filing. First, there is no information about the nature of the transaction represented by the statement. One would guess that this filing represents a purchase of the named equipment with a loan secured by the equipment, but it might also be a refinancing of the equipment or a new loan collateralized by equipment which Leary Brothers already owned. ${ }^{7}$ Second, there are no numbers of any kind relating to the loan amount, the terms of the loan, or the value of the collateral. Finally, there is relatively little information on the debtor or

\footnotetext{
${ }^{7}$ Although lessors need not file statements to retain ownership of leased equipment in the event of lessee bankruptcy, some lessors do file statements and may (or may not) indicate that they represent leases.
} 


\section{UCC FINANCING STATEMENT}

FOLLOW INSTRUCTIONS (front and back) CAREFULLY

A. NAME \& PHONE OF CONTACT AT FILER [optional]

UCC DEPARTMENT 1-888-427-8713

B. SEND ACKNOWLEDGMENT TO: (Name and Address)

\section{JOHN DEERE CREDIT \\ 6400 NW 86TH STREET \\ P.O. BOX 6630 \\ JOHNSTON, IA 50131}

THE ABOVE SPACE IS FOR FILING OFFICE USE ONLY

1. DEBTOR'S EXACT FULL LEGAL NAME-insert oniy one debtor name (1a or 1 b)-donotabbreviate or combine names

\section{1a. ORGANIZATION'S NAME \\ LEARY BROTHERS LOGGING, INC.}

\begin{tabular}{|c|c|c|c|c|c|}
\hline \multicolumn{2}{|c|}{ OR 16. INDIVIDUAL'SLASTNAME } & \multirow{2}{*}{\begin{tabular}{|l} 
FIRST NAME \\
CITY \\
\end{tabular}} & \multicolumn{2}{|c|}{ MIDDLE NAME } & \multirow{2}{*}{\begin{tabular}{|l|} 
SUFFIX \\
COUNTRY
\end{tabular}} \\
\hline 1c. MAILING ADDRESS & & & STATE & POSTAL CODE & \\
\hline 5059 BROWN & EK CHURCH RD & WADESBORO & NC & 28170 & USA \\
\hline 1d. SEEINSTRUCTIONS & \begin{tabular}{|l|l|} 
ADDLLINFO RE & 1e. TYPE OF ORGANIZATION \\
ORGANIZATION & CORP \\
DEBTOR & CORP
\end{tabular} & $\begin{array}{l}\text { 1f. JURISDICTION OF ORGANIZATION } \\
\text { NC }\end{array}$ & $\begin{array}{l}19 . \mathrm{ORG} \\
0263\end{array}$ & $\begin{array}{l}\text { NIZATIONAL ID \# } \\
24\end{array}$ & \\
\hline
\end{tabular}

2. ADDITIONAL DEBTOR'S EXACT FULL LEGAL NAME - insert only one debtor name (2a or 2b) - do not abbreviate or combine names

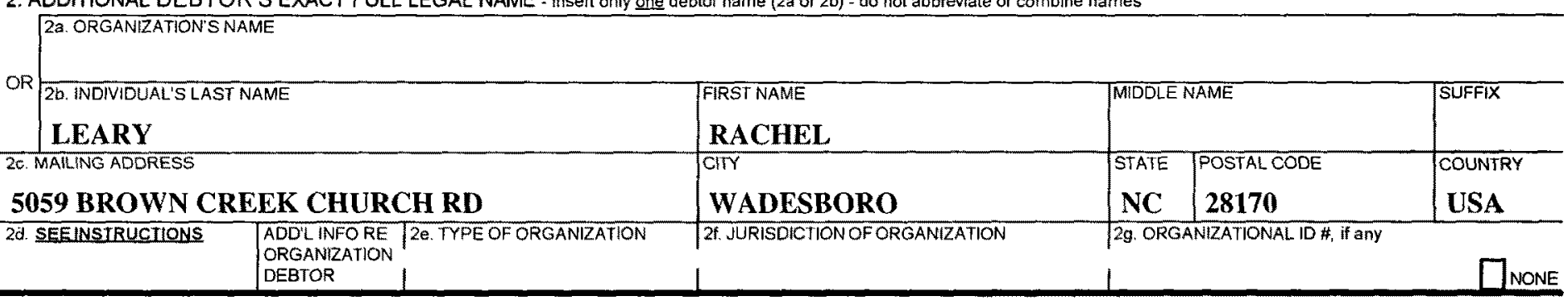

3. SECURED PARTY'S NAME (or NAME of TOTAL ASSIGNEE of ASSIGNOR SIP) - insertonly one secured party name (3a or 3b)

\section{3a. ORGANIZATION'S NAME \\ DEERE \& COMPANY}

OR 36. INDIVIDUAL'S LAST NAME

3c. MAILING ADDRESS

- 6400 NW 86TH ST

4. This FINANCING STATEMENT covers the following collateral:

John Deere 2520 Compact Utility Tractor $\mathrm{S} / \mathrm{N}: 208130$

Bush Hog TH60 Mower S/N: -08093

together with (1) all attachments, accessories and components, repairs and improvements, (2) all accounts, general intangibles, contract rights and chattel paper relating thereto, and (3) all proceeds, thereto including, without limitation, insurance, sale, lease and rental proceeds, and proceeds of proceeds. 
secured party beyond their names and addresses. ${ }^{8}$ It is also worth noting that the majority of UCC filings do not name specific collateral like this one does - most simply stake a secured claim in all of the debtor's assets.

\subsubsection{The California data}

Although maintains a database of financing statements and provides an interfaces for searching it, the states vary widely in the extent to which they make bulk data from the statements easily or cheaply available. ${ }^{9}$ In this paper, I use the dataset of filings from the state of California that was available at the end of June, 2011. UCC filings "lapse" after five years if they are not renewed, meaning they cease to serve as a legal claim-marker for the listed collateral. California purges lapsed filings from their dataset after one year, so the dataset covers all filings made between July 2005 and June 2011 (as well as any filings originally made prior to July 2005 that have been renewed since then). As the period covered by the data spans six years, with the mid-point falling between 2008Q2 and 2008Q3, it is natural to divide the sample into a three-year "preperiod" from 2005Q3 to 2008Q2 (before the fall of Lehman Brothers) and a three-year "postperiod" from 2008Q3 to 2011Q2. ${ }^{10}$ I will refer to these periods throughout the remainder of the paper.

The raw database of filings consists of unedited text fields from many thousands of filings like the one shown following page 11 . This raw text required a great deal of cleaning on the collateral descriptions and debtor and lender information to construct a usable dataset.

\footnotetext{
${ }^{8}$ The example statement includes an "Organizational ID \#," but not all states collect information like this.

${ }^{9}$ There are a number of factors that can make data from certain states difficult to access. For example, many filings are still submitted on paper forms in some states, and these states may sell databases of scanned images of the filings, rather than raw text. There is also wide variation in the prices at which states sell their bulk data. While some states charge as much as tens of thousands of dollars, California charges only $\$ 100$ for a one-time download. There are also some private firms that extract and clean text from the images and re-sell the data, but I was unable to reach an acceptable agreement with them to allow the use of their data for this paper.

${ }^{10}$ Note, however, that disruptions in the subprime market and signs of distress at major banks began as early as summer 2007. I nonetheless consider the preperiod to extend through 2008Q2 to avoid reducing the number of firms observed in the pre-period and thus the size of the sample of firms. By defining the preperiod to include 2007 q3 to 2008 q2 when distressed lenders may have already begun restricting the supply of credit, I may underestimate the effect of lender distress.
} 
Beginning with the collateral information, I must first note that the text of the collateral descriptions are available only for filings that were submitted electronically. ${ }^{11}$ More than sixty percent of filings were done electronically in the period covered by the data. I used Perl scripts to extract a measure of the number of pieces of equipment listed on each filing by simply counting the number of occurrences of distinctive brand names of manufacturers of construction machinery, farm machinery, trucks, copiers, and machine tools. ${ }^{12}$ This automated method of extracting the number of machines on each filing results in occasional overand under-counts. However, I hand-inspected a random sample of 100 filings and found that this method produced the correct count in $95 \%$ of filings. I make no attempt to estimate the size or value of the machines listed in filings.

I clean the text of the debtor names extensively to assure that I correctly link together multiple filings associated with the same debtor (as debtor name is the only identifier available). It is worth noting that debtor names on the filings must match debtors' legal names according to certain legally-defined standards in order to hold sway in court; however, typos and name variations are still common. For firm debtors, I capitalize names, remove punctuation and spaces, fix common typos, expand common abbreviations, and remove common end-words (Inc, LLC, etc.). For individuals - the debtor on many filings is simply the name of an individual, presumably a sole proprietor - I capitalize and remove punctuation, and append the first three digits of the individual's zipcode to avoid lumping together common names from across the state. In general, I attempt to err on the side of incorrectly lumping together debtors that are actually unaffiliated, rather than failing to link together multiple filings for the same debtor. This practice should bias my results away from finding that

\footnotetext{
${ }^{11}$ Collateral descriptions from paper filings are visible in the scanned images that can also be purchased from the state of California.

${ }^{12}$ Example brand words include Caterpillar, Deere, Bobcat, Volvo, Peterbilt, Xerox, Konica, Haas, and Mori-Seiki, among many others. I inspected the data on all manufacturers in the list, and I excluded manufacturer names that frequently matched text that did not refer to a piece of equipment (for example, Case). I also handled the convention of listing multiple machines by indicating the number of machines in parentheses, for example, TWO (2) GRADALL MODEL 544D TELEHANDLERS SERIAL NUMBERS 0160028457 \& $0160028534 . "$
} 
Figure 1: Size of firms in the data

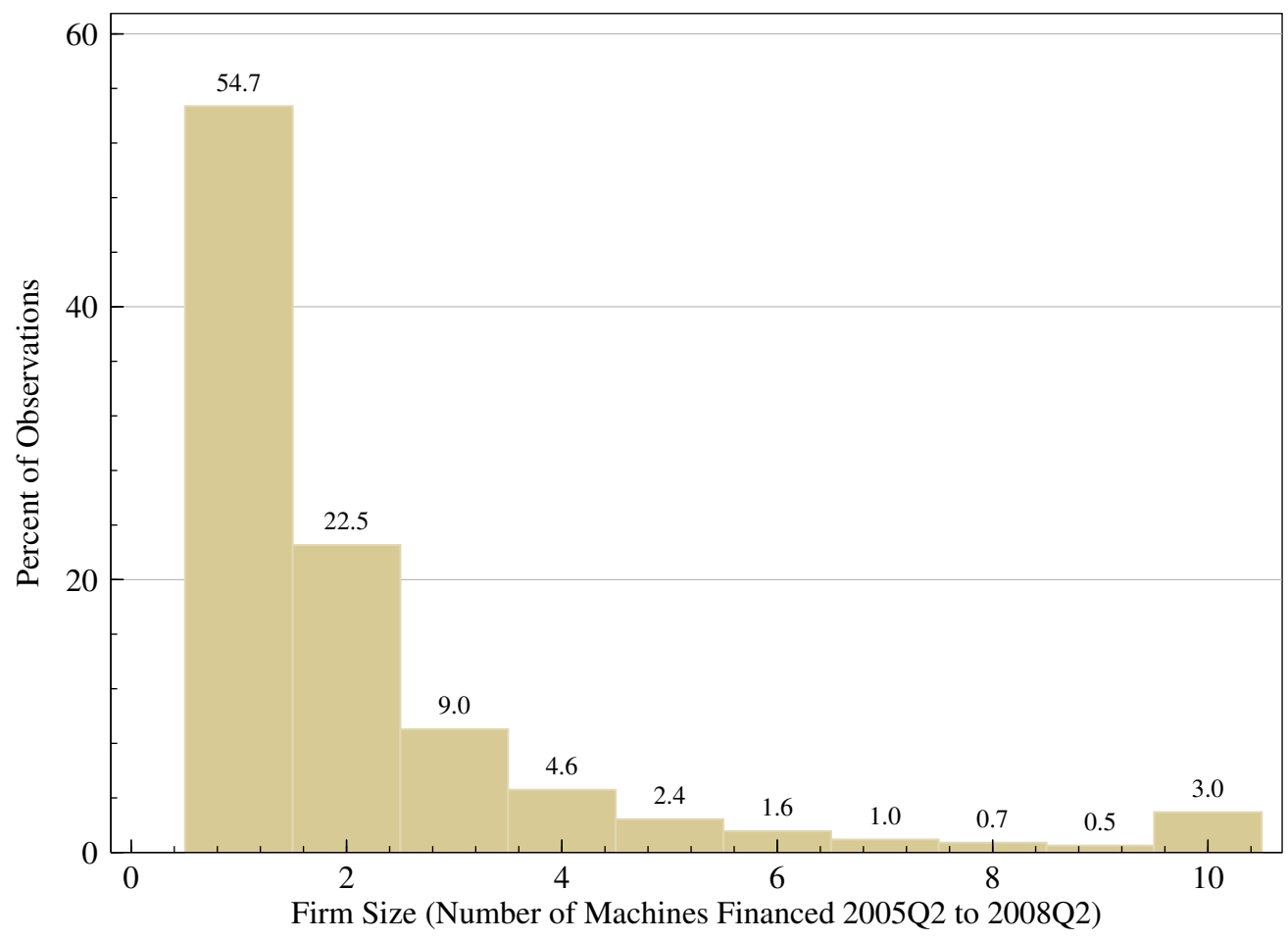

Rightmost bin includes all firms with 10 or more machines.

firms dependent on distressed lenders were less likely to finance equipment after the crisis. ${ }^{13}$

Figure 1 presents a histogram of the number of machines financed in the preperiod by the firms in the data. A majority (55\%) of firms observed in the preperiod appear as financing just a single machine. Firms financing two to four machines account for $36 \%$ of firms in the data, and firms financing five or more machines for $9 \%$. Although there is no way to map the number of machines financed over a three-year period directly into more standard firm size metrics like total assets or employees, it seems that most firms appearing in the data would be considered "small businesses." Indeed one could also reach this conclusion by selecting a random sample of the firms in the data and investigating them online - most would meet one's intuitive definition of a "small business." 14

\footnotetext{
${ }^{13}$ For example suppose "Johnson Brothers Construction, LLC" was financing equipment with a bank that failed during the crisis, so they had to find a new lender. However, suppose the new lender lists the same firm on its UCC filings as "Johnson Bros. Construction, Inc." If I were not cleaning and standardizing the names as described, I would incorrectly conclude that the firm had ceased financing equipment. On the other hand, accidentally lumping together two firms that are actually separate entities is innocuous.

${ }^{14}$ In fact, it also appears that large businesses are underrepresented in the data. For example, the very
} 
I similarly clean and standardize the text of the secured party names. I also handinspected all of the secured parties that ever financed fifteen or more pieces of equipment in a single year (which encompasses more than $90 \%$ of pieces financed) and classified them into several categories: banks (or bank-owned finance companies), captive finance companies (e.g. Caterpillar Financial Services, Kubota Credit), other finance companies (i.e. not bankowned or manufacturer-affiliated), and all other lenders (the most common are equipment dealers). ${ }^{15}$

Figure 2 presents data on the number of machines financed in each quarter by the type of secured party. There are around 7,500 machines from the list of manufacturers that I capture that are visible in the data in each quarter in 2006, before the crisis began. Banks and captive finance companies accounted for about 3,000 machines each, with other finance companies also contributing 1,000 machines.

The bottom panel of Figure 2 presents the same data, but indexed so that the observations from 2007Q2, before any financial turmoil began, are equal to one. There are large declines in the number of machines financed by all lender types. For example, the number of machines financed by captive finance companies fell by 50\% between 2007Q2 and 2009Q3. However, the number of machines financed by banks and independent finance companies fell noticeably more steeply than those financed by captive finance companies and other lenders (which includes many equipment dealers). Further, the number of machines financed by banks was only narrowly above its post-crisis trough by early 2011 . These facts already suggest that distress among banks and independent finance companies may have played a role in observed declines in equipment investment.

largest construction firms (identified from other sources) appear only sporadically in the data. As these firms must be very large equipment users, their frequent absence suggests that they finance most of their equipment without using secured loans, or possibly just through lenders that do not file UCC statements for some reason. This ambiguity surrounding selection into the UCC filing universe is a shortcoming of the data.

${ }^{15}$ For the other secured parties that I did not hand-inspect, I classified them as banks if their name contained the words "bank" or "bancorp" and as other finance companies if their names contained any variations on words like "finance," "credit," "capital," etc. 
Figure 2: Total number of machines financed, by secured party type
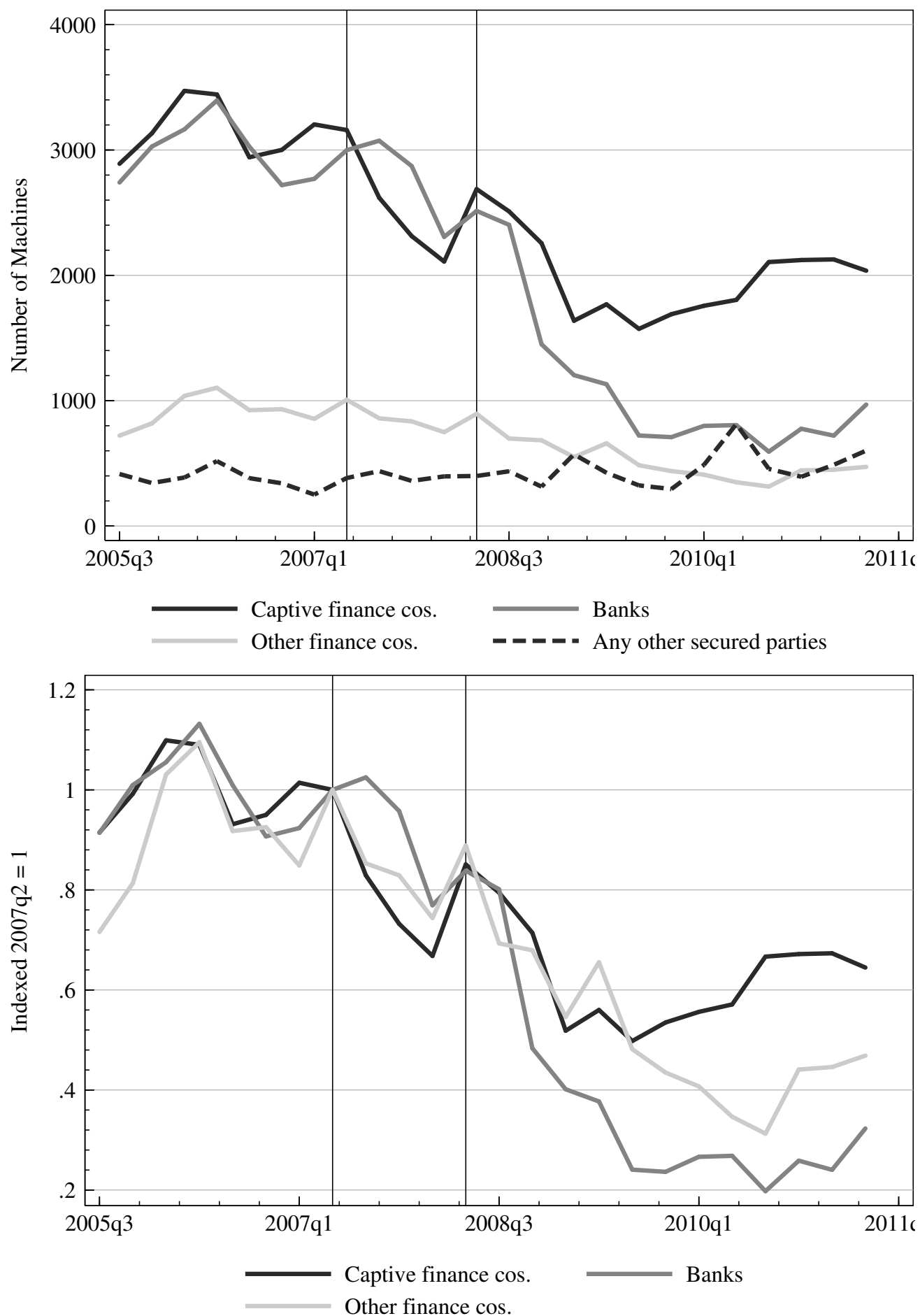

Vertical lines intersect observations for 2007q2 and 2008q2. Figures exclude machines financed by Kubota Credit Corporation, a large captive finance company that began reporting electronically in mid-2008. 


\section{$3.2 \quad$ Distressed lenders}

This paper measures how equipment financing by firms dependent on "distressed lenders" differed from financing by other firms after the crisis. I focus on three types of distressed lenders: "problem" banks, bankrupt finance companies, and Citigroup.

I denote as "problem" banks all banks that failed prior to July 2011 or that appeared on the "Unofficial problem bank list" posted on the Calculated Risk Blog as of July 2011. Banks appear on the problem list when public enforcement actions have been taken against them by regulators. As examples, the largest secured parties (by number of machines financed) on my list of problem banks include Irwin Commercial Finance, PFF Bank and Trust, and Pacific Capital Bank. Irwin Commercial Finance was a subsidiary of Irwin Financial Services, Inc., which was brought down by the failure of Irwin Union Bank in September 2009. PFF Bank and Trust failed in November, 2008, and Pacific Capital Bank received a "consent order" from the OCC in May 2010, indicating that the bank was under-capitalized and ordering it to raise capital.

I also include as "distressed lenders" two finance companies that declared bankruptcy. CIT Group was a major equipment financier before the crisis, primarily serving small and medium-sized businesses. It converted to a bank holding company during the crisis to get access to the discount window, but still became severely distressed, in part due to exposure to subprime housing lending. It lobbied for a bailout, but did not receive one, and entered bankruptcy in November 2009. Sunbridge Capital, another finance company, financed a similar number of machines in California during the preperiod, and it entered bankruptcy proceedings in April 2009.

Finally, Citigroup (operating through its commercial finance subsidiaries) is the single largest lender in the California data in the pre-period, ${ }^{16}$ and it is known to have been severely distressed during the crisis period. In fact, regulators debated taking actions against

\footnotetext{
${ }^{16}$ Citigroup had a relationship with Bobcat (the iconic maker of skid-steer loaders and other construction equipment) such that it performed a role like a captive finance company for Bobcat. Most, but not all, of the equipment financed by Citigroup consisted of Bobcats.
} 
Table 1: List of largest lenders in California UCC data in 2006

$\begin{array}{rrl}\text { Rank } & \text { Machines } & \text { Lender } \\ 1 & 4824 & \text { CITIGROUP } \\ 2 & 3752 & \text { DEERE \& CO. } \\ 3 & 3412 & \text { CATERPILLAR FINANCIAL } \\ 4 & 2598 & \text { CNH CAPITAL } \\ 5 & 1577 & \text { KUBOTA CREDIT } \\ 6 & 1067 & \text { USBANCORP } \\ 7 & 1001 & \text { BANK OF AMERICA } \\ 8 & 931 & \text { WELLS FARGO } \\ 9 & 651 & \text { FCC EQUIPMENT FINANCING } \\ 10 & 497 & \text { TOYOTA MOTOR CREDIT } \\ 11 & 480 & \text { GENERAL ELECTRIC CAPITAL } \\ 12 & 468 & \text { XEROX } \\ 13 & 461 & \text { CIT GROUP } \\ 14 & 429 & \text { RABOBANK } \\ 15 & 370 & \text { RICOH CUSTOMER FINANCE } \\ 16 & 342 & \text { SUNBRIDGE CAPITAL } \\ 17 & 265 & \text { EQUILEASE FINANCIAL SERVICES } \\ 18 & 257 & \text { NAEDA FINANCIAL BANK } \\ 19 & 231 & \text { GREATER BAY BANK } \\ 20 & 229 & \text { KONICA-MINOLTA } \\ 21 & 220 & \text { USEXPRESS LEASING } \\ 22 & 214 & \text { HITACHI CAPITAl } \\ 23 & 213 & \text { PRODUCTIVE FINANCE } \\ 24 & 209 & \text { CNC ASSOCIATES } \\ 25 & 208 & \text { WEBSTER BANK } \\ 26 & 203 & \text { CUMMINSWEST } \\ 27 & 199 & \text { IRWIN UNION BANK } \\ 28 & 198 & \text { DIVERSIFIED FINANCIAL SERVICES } \\ 29 & 198 & \text { TCF BANK } \\ 30 & 191 & \text { RDO EQUIPMENT } \\ 31 & 187 & \text { KOMATSU FINANCIAL } \\ 32 & 183 & \text { UNITED RENTALS } \\ 33 & 181 & \text { VOLVO FINANCIAL } \\ 34 & 178 & \text { ZIONS BANK } \\ 35 & 172 & \text { FORD MOTOR CREDIT } \\ 36 & 165 & \text { NAVISTAR FINANCIAL } \\ 37 & 155 & \text { INTECH FUNDING } \\ 38 & 140 & \text { FIRST NATIONAL EQUIPMENT BANK } \\ 39 & 133 & \text { PETERSON TRACTOR } \\ 40 & 128 & \text { MARLIN BUSINESS BANK } \\ 41 & 122 & \text { JOHNSON MACHINERY } \\ 42 & 119 & \text { BANK OF THE WEST } \\ 43 & 101 & \text { CALIFORNIA FIRST NATIONAL BANK } \\ 44 & 95 & \text { COMERICA BANK } \\ 45 & 95 & \text { KEYBANK } \\ 46 & 86 & \text { PACIFIC CAPITAL BANK } \\ 47 & 85 & \text { NATIONAL CITY BANK } \\ 48 & 82 & \text { EXCHANGE BANK } \\ 49 & 74 & \text { PFF BANK AND TRUST } \\ 50 & & \\ & & \end{array}$

Highlighted lenders are deemed "distressed" as described in the text. 
Citigroup that would have resulted in it being deemed a problem bank, but they did not (see Paletta and Enrich [2009] in the Wall Street Journal).

Table 1 lists the largest 50 lenders in the data in 2006, by number of machines financed. The lenders I deem "distressed" are highlighted. They are sprinkled throughout the distribution of lenders.

\section{Empirical approach and identification}

This paper's empirical strategy is to relate firms' equipment financing in the post-crisis period to their pre-crisis reliance on lenders that would become distressed during the crisis. In particular, I run regressions of the following form,

$\frac{\text { PostPeriodMachinesFinanced }_{i}}{\text { PrePeriodMachinesFinanced }_{i}}=\beta \frac{\text { PrePeriodMachinesFinancedByDistressedLender }_{i}}{\text { PrePeriodMachinesFinanced }_{i}}+\Gamma^{\prime} X_{i}+\epsilon_{i}$,

where $i$ indexes firms and the sample consists of all firms that are observed financing at least one machine in the preperiod. The dependent variable is the ratio of machines financed in the postperiod to machines financed in the preperiod. ${ }^{17}$ The key independent variable is the fraction of machines in the preperiod financed by lenders that became distressed during the crisis.

There are clear reasons why one could worry that an OLS estimate of $\hat{\beta}$ might not provide an unbiased estimate of the causal effect of lender distress on firm investment. For example, one could worry about reverse causality, in that firms that became distressed during the crisis might have caused their banks to become distressed as well, perhaps by withdrawing deposits. More likely, however, might be a concern about selection on unobservables. That is, it might be that lenders who were unwise enough to become distressed during the crisis were also unwisely lending to weaker firms or to firms more susceptible to the recession.

In response to these concerns, I would first argue that we should still study events sur-

\footnotetext{
${ }^{17} \mathrm{I}$ winsorize this variable at 2 , which is around its 97 th percentile.
} 
rounding the financial crisis even if extremely clean quasi-experimental evidence is not available. The financial crisis and recession are the most important economic events of the last several decades, and new evidence on what exactly occurred during this period would be valuable, even if it were only descriptive. Second, I suspect that many readers would be willing to assume that banks and other lenders that became distressed during the crisis did so due to their exposure to real estate (which, of course, experienced an historic collapse) and would be willing to consider this distress to be roughly exogenous to the banks' equipment lending customers. Indeed, I have yet to hear of a bank that is said to have failed on account of its equipment lending portfolio. ${ }^{18}$

Third, I do my best in the specifications presented to control flexibly for observable firm characteristics. In particular, I include detailed sets of fixed effects for firm location, industry, and size, and their interactions. These specifications thus mimic the experiment of comparing two firms in the same county, in the same industry, and of the same size, where one firm financed equipment from a lender that became distressed during the crisis and the other did not.

Finally, motivated in part by the identification strategy of Khwaja and Mian [2008], I also investigate firms' substitution towards lenders that did not become distressed. Again, I find that firms that had depended on lenders that became distressed increased their borrowing from nondistressed lenders relative to comparable firms, suggesting that these firms experienced a tightening in the credit supplied by the distressed lenders, rather than an overall decline in credit demand.

Table 2 presents a simple example of the kind of comparison that will be inherent in the regression results to come. Weber-Madgwick Excavating and Mike Drews Construction are both located in Los Angeles County, California. Both firms financed five pieces of construction equipment in the pre-crisis period, and these are listed in the table. Weber-Madgwick financed four of its five pieces through CitiCapital Commercial Finance, a subsidiary of Cit-

\footnotetext{
${ }^{18}$ Of course, one can never fully rule out the notion that banks that made particularly unwise real estate loans might also have made particularly unwise equipment loans.
} 
Table 2: Example of comparison from fixed effects specifications

Preperiod financing

Weber-Madgwick Excavating

Sep. 2005 Case New Holland Capital Caterpillar 963B Crawler Loader

Oct. 2005 CitiCapital Commercial

Bobcat S130 Skid Steer Loader

Dec. 2005 CitiCapital Commercial

Komatsu D755 Crawler Loader

Apr. 2006 CitiCapital Commercial

Bobcat T300 Track Loader

June 2008 CitiCapital Commercial

Mike Drews Construction

Dec. 2005 FCC Equipment Financing

June 2006 Caterpillar Financial

Bobcat S130 Skid Steer Loader

Sep. 2007 Case New Holland Capital

Caterpillar 321C Excavator

Caterpillar 277B Track Loader

Oct. 2007 Case New Holland Capital New Holland TC55DA Wheel Loader

Dec. 2007 Caterpillar Financial

Caterpillar 287C Track Loader

Postperiod financing

Weber-Madgwick Excavating

None.

Mike Drews Construction

Sep. 2009 Volvo Financial Services

Volvo ECR145CL Excavator

Oct. 2009 John Deere \& Company

Deere 17DX Compact Excavator

Feb. 2010 Caterpillar Financial

Caterpillar 330CL Excavator

Weber-Madgwick Excavating and Mike Drews Construction are both located in Los Angeles County, California. Both financed five pieces of construction equipment in the pre-crisis period. Weber-Madgwick financed four of its five pieces through CitiCapital Commercial Finance, a subsidiary of Citigroup, while Mike Drews financed its equipment through other lenders. After the crisis (during which Citigroup became extremely distressed and exited the equipment lending business), Weber-Madgwick does not appear in the data as financing any additional equipment, while Mike Drews does.

igroup, while Mike Drews financed its equipment through other lenders. Citigroup was hit hard by the financial crisis and recorded tens of billions of dollars of losses during 2008 on its exposures to subprime mortgage loans and CDOs, Alt-A mortgage securities, commercial real estate holdings, and structured investment vehicles. To raise cash, Citigroup split up and sold its equipment financing businesses in July, 2008. After the crisis Weber-Madgwick does not appear in the data as financing any additional equipment, while Mike Drews finances three more pieces.

This example illustrates this paper's empirical strategy, along with its potential pitfalls. The two firms in the example are observably quite similar-both are located in the same 
county in California, and both financed a similar number and type of machines before the crisis. In fact, the Bobcat S130 and T300 financed by Weber-Madgwick are very similar to the Caterpillar 277B and 287C financed by Mike Drews. It is thus reasonable to think that average differences in postperiod equipment financing over many pairs of firms like these would be driven by the firms' dependence on different lenders.

On the other hand, one cannot conclusively rule out the possibility that unobserved attributes of firms like Weber-Madgwick are correlated with these firms' propensities to borrow from lenders that would become distressed. For example, it is feasible that lenders like Citigroup, which took on more exposure to risky real estate than did other lenders, were also willing to finance equipment for borrowers that were riskier in ways that are unobservable in the UCC data. As noted, however, I do show that other firms like Weber-Madgwick that relied on distressed lenders were more likely to increase their borrowing from non-distressed lenders, although this increase does not occur in this particular example.

\section{Results}

\subsection{Aggregates}

I first classify firms into groups by their pre-crisis dependence on certain lenders. In particular, I consider all machines financed by a given firm in the three year preperiod from $2005 q 3$ to 2008 q2 (from when the data begin to the quarter before the financial crisis became severe). For each firm, I calculate the fraction of all machines it financed during this period that were financed by lenders that would later become distressed. That is, I classify firms into groups based on the post-crisis status of their pre-crisis lenders.

Figure 3 presents the paper's main result in aggregate chart form. The black line displays the total number of machines financed in each quarter (indexed to 2007Q2) by firms that financed at least $50 \%$ of their pre-crisis equipment through lenders that later became distressed. The grey line displays the total number of machines financed by all other firms 
that financed at least $50 \%$ of their pre-period machines with a single lender. The decline in the grey line shows the baseline behavior of businesses that were financing equipment in the years before the crisis. It declines steeply due to both the decline in investment among firms that remained active and the propensity of small businesses to fail or otherwise disappear from the sample. ${ }^{19}$

Most importantly, the black line remains considerably below the grey line. This indicates that businesses that had relied heavily on lenders that became distressed during the crisis reduced the number of machines that they financed more than did other businesses. In fact, the effect here looks quite large - the black line is about half of the grey line for most of the postperiod. Figure 4 breaks out the three groups of distressed lenders that made up the black line in Figure 3. Although the machines financed by the different groups of lenders do not move in lockstep in the preperiod, the postperiod decline is apparent in all three groups.

\footnotetext{
${ }^{19}$ That is, even in the absence of a severe recession, if I chose a group of firms by identifying all firms that appear in the data in a three-year period and then counted the number of machines financed by those same firms in the subsequent three-year period, there would likely be a steep decline from the first to the second period because many of the firms observed in the first three years do not appear again.
} 


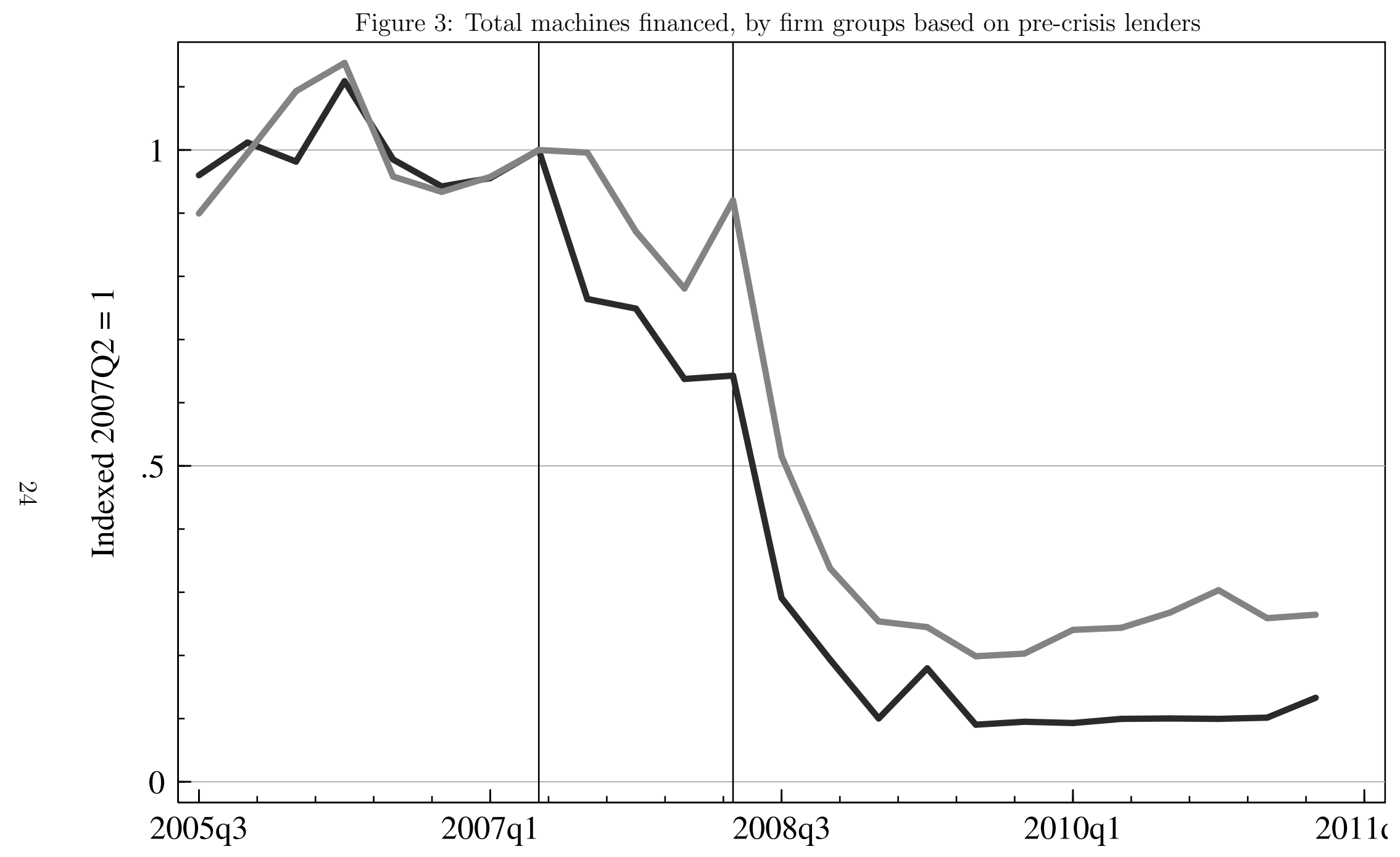

Firms $>=50 \%$ financed in $05 \mathrm{Q} 3$ to $08 \mathrm{Q} 2$ by any lender that later became distressed

Firms $>=50 \%$ financed in $05 \mathrm{Q} 3$ to $08 \mathrm{Q} 2$ by any other single lender

Vertical lines intersect the observations for 2007q2 and 2008q2. 
Figure 4: Total machines financed, by firm groups based on pre-crisis lenders, with detail on distressed lenders

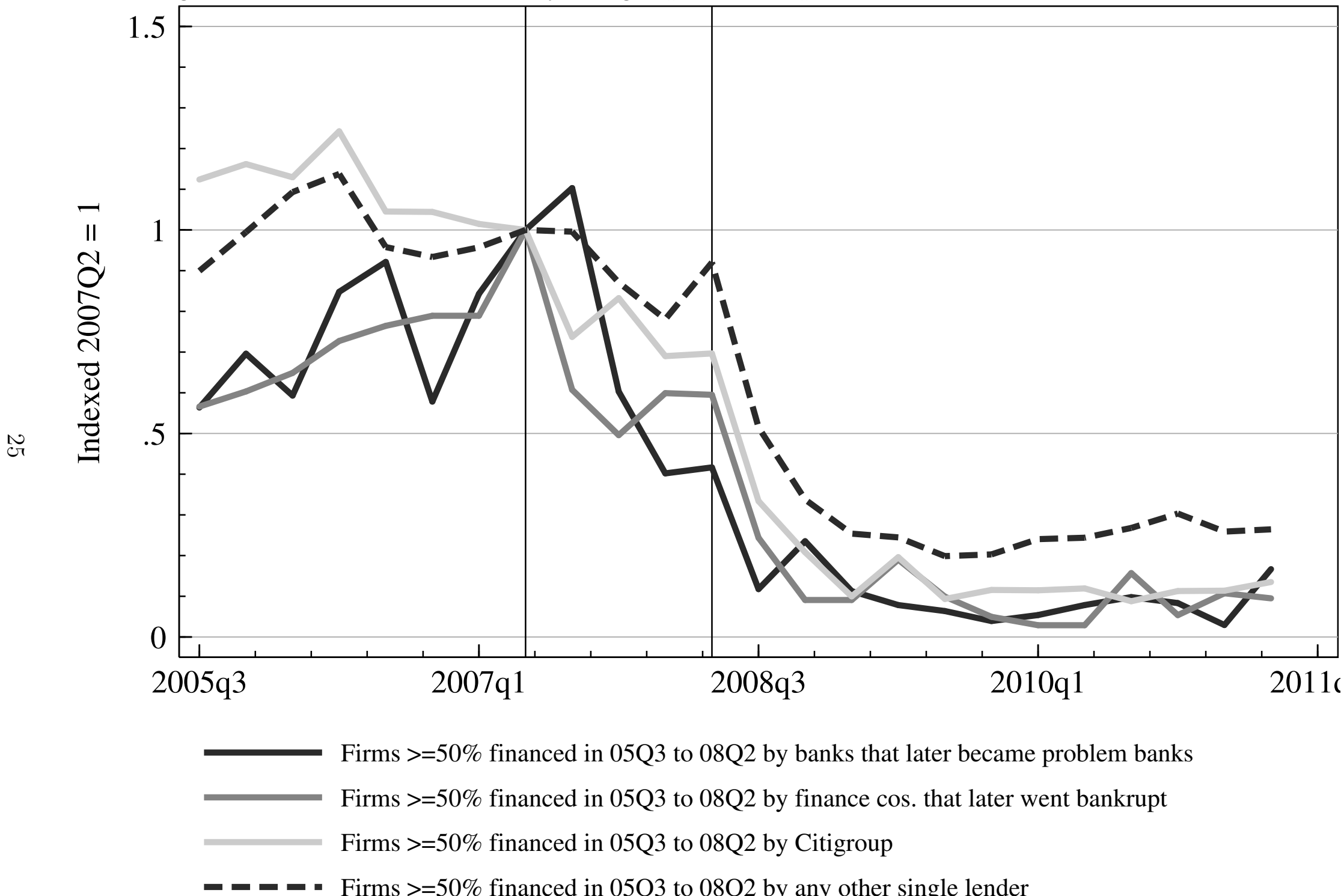

Vertical lines intersect the observations for $2007 \mathrm{q} 2$ and $2008 \mathrm{q} 2$. 


\subsection{Regressions}

Table 3 presents regression results that quantify and refine the story from figures 3 and 4. Column 1 is essentially descriptive statistics. The constant indicates that the average postperiod/preperiod investment ratio among firms that financed no preperiod machines through distressed lenders is 0.2 . This low value reflects the fact that most firms that appear in a UCC filing in the preperiod never appear again in the postperiod. The coefficients in column 1 indicate that firms 100\% financed by distressed lenders have an investment ratio about 0.1 (or $50 \%$ ) lower than the average firm $0 \%$ financed by a distressed lender. Coefficients are statistically significant at the one percent level when clustering by modal preperiod lender; standard errors are lower than these if unclustered or clustered by county.

Column 2 adds variables equal to the percent of each firm's preperiod machines financed by any bank or any finance company. The bank coefficient is negative (although not statistically significant), and coefficients on the distressed lender variables fall somewhat, suggesting that part of the effect of the distressed lenders is shared with all banks. ${ }^{20}$ Column 3 adds a variable for "lender diversity" equal to 1 minus the percent of preperiod machines financed by the modal preperiod lender (and thus equal to zero for firms financed entirely by a single lender). The coefficient on this variable is large and highly statistically significant, but including it has only minor effects on the distressed lender coefficients.

The next columns in the table add fixed effects. Column 4 includes dummy variables to control for fixed effects for each of the 58 counties in California, for 6 bins of firm size, ${ }^{21}$ and for each of six categories of the modal type of equipment financed by each firm. ${ }^{22}$

\footnotetext{
${ }^{20}$ This all-bank effect could also have been caused by credit supply restrictions associated with the financial crisis.

${ }^{21}$ Again, firm size is measured by the number of machines financed in the preperiod. The firm size bins are for 1 machine, 2 machines, 3 to 5 machines, 6 to 10 machines, 11 to 25 machines, and 26 or more machines. Changing the size bin definitions has no noticeable effects on results.

${ }^{22}$ The equipment types are contruction machinery, farm machinery, trucks, copy machines, lift trucks, and all others (primarily machine tools). The equipment types are defined by manufacturer, which introduces some mismeasurement. For example, I count all John Deere equipment as farm machinery, although some John Deere equipment is, in fact, construction machinery. I have also used industry dummies constructed from words appearing in firm names in place of the equipment types, and results are quite similar.
} 
Table 3: Regressions of postcrisis/precrisis investment ratio on percent of precrisis financing by distressed lenders and controls

\begin{tabular}{lccccc} 
& $(1)$ & $(2)$ & $(3)$ & $(4)$ & $(5)$ \\
\cline { 2 - 6 } & -.106 & -.094 & -.088 & -.050 & -.066 \\
Pct. Financed by Citigroup & $(.018)^{* * *}$ & $(.017)^{* * *}$ & $(.016)^{* * *}$ & $(.014)^{* * *}$ & $(.010)^{* * *}$ \\
Pct. Financed by Other Distressed Lenders & -.100 & -.091 & -.092 & -.065 & -.066 \\
& $(.030)^{* * *}$ & $(.028)^{* * *}$ & $(.026)^{* * *}$ & $(.019)^{* * *}$ & $(.012)^{* * *}$ \\
Pct. Financed by Any Bank & & -.018 & -.018 & -.001 & .005 \\
& & $(.022)$ & $(.021)$ & $(.016)$ & $(.010)$ \\
Pct. Financed by Any Finance Co. & & -.003 & .001 & .020 & .009 \\
& & $(.024)$ & $(.024)$ & $(.016)$ & $(.010)$ \\
Lender Diversity & & & .329 & .280 & .305 \\
& & & $(.030)^{* * *}$ & $(.038)^{* * *}$ & $(.020)^{* * *}$ \\
Constant & .204 & .211 & .192 & .178 & .175 \\
& $(.018)^{* * *}$ & $(.017)^{* * *}$ & $(.017)^{* * *}$ & $(.020)^{* * *}$ & $(.009)^{* * *}$ \\
County Fixed Effects (FE) & & & & Yes & Yes \\
Firm Size FE & & & & Yes & Yes \\
Industry (Equipment Type) FE & & & & Yes & Yes \\
County $\times$ Size $\times$ Industry FE & & & & & Yes \\
Observations & 37794 & 37794 & 37794 & 37794 & 37794 \\
$R^{2}$ & .007 & .007 & .016 & .053 & .078 \\
\hline \hline
\end{tabular}

The dependent variable is the ratio of the number of machines financed between 2008q3 and 2011q2 to the number financed between 2005q3 and 2008q2. Independent variables refer to precrisis firm characteristics. Standard errors (in parentheses) are clustered by modal preperiod lender.

Including these sets of fixed effects does noticeably lower the coefficients on the distressed lender variables, but they remain economically and statistically significant. Column 5 further introduces dummy variables for the full set of three-way interactions among the county, size, and equipment type fixed effects.

Column 5 thus most closely mimics the earlier example comparing Weber-Madgwick Excavating and Mike Drews construction. That is, the average investment ratio in any county-size-industry combination (in the example, Los Angeles County-3 to 5 preperiod machines - construction industry) is absorbed by the fixed effect, and the distressed lender coefficients are estimated only from variation within these county-size-industry cells. Both of the distressed lender coefficients are equal to -0.066 in this specification. Compared to the baseline of 0.2 from non-distressed-lender dependent firms in column 1, this coefficient represents about a $30 \%$ reduction in postperiod investment by firms $100 \%$ financed by distressed 
Table 4: Robustness tests: Regressions of postcrisis/precrisis investment ratio on percent of precrisis financing by distressed lenders and controls

\begin{tabular}{lccccc} 
& $(1)$ & $(2)$ & $(3)$ & $(4)$ & $(5)$ \\
\cline { 2 - 6 } & -.04 & -.02 & -.09 & -.06 & -.04 \\
Pct. Financed by Citigroup & $(.02)^{* *}$ & $(.01)$ & $(.02)^{* * *}$ & $(.01)^{* * *}$ & $(.02)^{* *}$ \\
Pct. Financed by Other Distressed Lenders & -.08 & -.09 & -.10 & -.06 & -.04 \\
& $(.02)^{* * *}$ & $(.02)^{* * *}$ & $(.03)^{* * *}$ & $(.02)^{* * *}$ & $(.02)^{*}$ \\
Pct. Financed by Any Bank & .02 & .02 & .00 & .00 & .01 \\
& $(.02)$ & $(.02)$ & $(.02)$ & $(.02)$ & $(.02)$ \\
Pct. Financed by Any Finance Co. & .004 & .02 & .006 & .01 & -.01 \\
& $(.02)$ & $(.02)$ & $(.02)$ & $(.02)$ & $(.02)$ \\
Lender Diversity & .32 & .20 & .30 & .28 & .19 \\
& $(.05)^{* * *}$ & $(.04)^{* * *}$ & $(.04)^{* * *}$ & $(.03)^{* * *}$ & $(.05)^{* * *}$ \\
County $\times$ Size $\times$ Industry FE & Yes & Yes & Yes & Yes & Yes \\
Observations & 25349 & 13377 & 37794 & 33627 & 37794 \\
$R^{2}$ & .09 & .09 & .2 & .07 & .06 \\
\hline
\end{tabular}

The dependent variable is the ratio of the number of machines financed between 2008q3 and 2011q2 to the number financed between 2005q3 and 2008q2. Independent variables refer to precrisis firm characteristics. All columns include county-industry-size fixed effects as in column 5 of Table 3. Standard errors (in parentheses) are clustered by modal preperiod lender.

Column 1 excludes firms financing construction equipment.

Column 2 excludes firms financing construction and farm equipment.

Column 3 weights observations by firm size.

Column 4 excludes several large lenders that increased their portion of electronic filings.

Column 5 uses the ratio of filings in the post versus preperiods as the dependent variable.

lenders.

Table 4 presents several robustness tests. As the construction industry was at the epicenter of the crisis and recession, one might like to verify that credit supply effects appear in other industries as well. Column 1 excludes firms in the construction industry from the sample (again, measured as firms whose modal preperiod machine was in the construction category), and column 2 excludes farm machinery financers as well. Although the Citigroup coefficient falls somewhat in magnitude and loses statistical significance in column 2 , the coefficient on other distressed lenders rises in magnitude and remains highly significant, despite the large reduction in sample size.

As one might also worry that small firms with only one preperiod machine might drive results despite accounting for only a small portion of aggregate investment, column 3 weights 
observations by preperiod firm size (again measured by number of preperiod machines appearing in the data). The distressed lender coefficients actually increase in magnitude and remain statistically significant.

Columns 4 and 5 perform tests intended to alleviate the concern that the absence of collateral descriptions from paper filings might affect results. There are a few large lenders that had a large increase in the portion of their filings done electronically during the period under study, and column 4 simply excludes all observations from these lenders. ${ }^{23}$ This exclusion has little effect on results. Column 5 uses all firms and lenders, but an alternate dependent variable - the ratio of total filings in the post versus preperiods, rather than the ratio of total machines appearing on filings. Thus, if a firm that had borrowed from a failed bank was able to find another lender in the postperiod-but that lender submitted filings only on paper - this specification would detect no drop in their filings (in contrast to earlier specifications, which would see a spurious drop in the number of machines appearing on electronic filings). Coefficients on the distressed lender variables do fall a bit in this specification (although they are not directly comparable to baseline results due to the change in dependent variable), but remain statistically significant at the 10 percent level or better.

\subsection{Substitution away from distressed lenders}

The next set of results in Tables 5 and 6 investigates the extent to which firms that depended on lenders that became distressed were able to substitute to financing machinery through other lenders. These tests serve two purposes. First, they serve to corroborate the interpretation of prior results as evidence of causal effects of credit supply. Results will show that firms that had depended on lenders that became distressed actually increased their borrowing from other lenders relative to comparable firms, where one might have expected them to decrease their borrowing from these other lenders if their decline in overall borrowing were driven by unobserved firm characteristics and not by their dependence on distressed

\footnotetext{
${ }^{23}$ The lenders are Kubota Credit, Toyota Motor Credit, Bank of the West, and Farm Credit West.
} 
Table 5: Regressions measuring tendency for firms dependent on distressed lenders to increase borrowing from non-distressed lenders

\begin{tabular}{lccccc}
\cline { 2 - 5 } & $(1)$ & $(2)$ & $(3)$ & $(4)$ & $(5)$ \\
\hline Pct. Financed by Distressed Lenders & .109 & .191 & .071 & .058 & .052 \\
& $(.070)$ & $(.052)^{* * *}$ & $(.065)$ & $(.042)$ & $(.052)$ \\
Lender Diversity & & .122 & .216 & .026 & -.058 \\
& & $(.088)$ & $(.130)^{*}$ & $(.083)$ & $(.047)$ \\
Constant & .344 & .281 & -.422 & -.220 & -.054 \\
& $(.021)^{* * *}$ & $(.037)^{* * *}$ & $(.089)^{* * *}$ & $(.066)^{* * *}$ & $(.037)$ \\
County $\times$ Size $\times$ Industry FE & & Yes & Yes & Yes & Yes \\
Observations & 4406 & 4406 & 4406 & 4406 & 4406 \\
$R^{2}$ & .002 & .16 & .2 & .191 & .188 \\
\hline
\end{tabular}

$\overline{\text { The sample consists of all firms that financed at least two preperiod machines, including at least one from }}$ a non-distressed lender.

In columns 1 and 2, the dependent variable is the ratio of the number of machines financed between 2008q3 and $2011 \mathrm{q} 2$ to the number financed between $2005 \mathrm{q} 3$ and $2008 \mathrm{q} 2$, with both the numerator and denominator including only machines financed through non-distressed lenders.

In column 3, it is the ratio of the change from pre to postperiod in the number of machines financed by captive finance companies to the total number of preperiod machines financed through non-distressed lenders.

In column 4, it is the ratio of the change from pre to postperiod in the number of machines financed by non-distressed banks to the total number of preperiod machines financed through non-distressed lenders.

In column 5 , it is the ratio of the change from pre to postperiod in the number of machines financed by other non-distressed finance companies to the total number of preperiod machines financed through non-distressed lenders.

Independent variables refer to precrisis firm characteristics. Standard errors (in parentheses) are clustered by modal preperiod lender.

lenders. ${ }^{24}$ Second, these results are interesting in their own right, in that they provide new information on the alternative sources of funding available to firms that had depended on lenders that became distressed.

Columns 1 and 2 of Table 5 present results that are similar to the baseline results in Table 3, except the dependent variable is the ratio of preperiod to postperiod machines financed through non-distressed lenders only. ${ }^{25}$ The sample is also limited to firms that financed machines through more than one lender in the preperiod. ${ }^{26}$ The key independent variable

\footnotetext{
${ }^{24}$ In similar settings in other countries, Khwaja and Mian [2008] and Iyer, Lopes, Peydro, and Schoar [2010] argue that results like these on firm borrowing from other lenders provide incontrovertible evidence that any overall declines in borrowing must be due to credit supply and not to unobservable firm characteristics that are correlated with firms' choices to borrow from lenders that would become distressed.

${ }^{25}$ That is, the numerator is the number of postperiod machines financed by non-distressed lenders, and the denominator is the number of preperiod machines financed by non-distressed lenders.

${ }^{26}$ Calculating the ratio requires at least one machine financed through a non-distressed lender in the preperiod. Any firms that had any machines financed through distressed lenders must therefore have had at least two preperiod lenders. As firms with more than one preperiod lender have higher investment ratios
} 
in the top row is also similar to those from the baseline results, but now lumps together Citigroup with the rest of the distressed lenders in a single variable.

While the negative coefficients on the distressed lender variables in Table 3 indicated that distressed-lender-dependent firms had lower overall investment ratios than comparable firms, the positive coefficients in Table 5 indicate that the distressed-lender-dependent firms had higher ratios when looking only at financing through the non-distressed lenders. That is, the firms that had been more dependent on lenders that became distressed during the crisis actually increased their financing through non-distressed lenders after the crisis relative to comparable firms, consistent with the notion that they were forced to substitute from the distressed lenders towards alternatives. In column 1, with no controls, this effect is statistically insignificant but economically large. In column 2, which includes the full set of county-size-industry fixed effects and interactions, the relevant coefficient is statistically significant at the one percent level and even larger in magnitude. ${ }^{27}$

Columns 3, 4, and 5 essentially decompose the overall impact on financing from nondistressed lenders in column 2 into effects on captive finance companies, non-distressed banks, and non-distressed other finance companies, although the coefficients need not sum exactly to that in column 2. The dependent variable in column 3 is the change from preperiod to postperiod in the number of machines financed by captive finance companies divided by the total number of preperiod machines financed through non-distressed lenders (the same denominator as in columns 1 and 2). Columns 4 and 5 are similar, but use changes in the number of machines from non-distressed banks and other non-distressed finance companies.

than other firms, I limit the sample to include only firms with more than one preperiod lender for the firms that did not borrow from any distressed lenders as well.

${ }^{27}$ One might worry that a normal process of mean reversion is at work in this result. That is, suppose a firm borrows unusually heavily from any single lender when compared to other firms in the same county and industry. Perhaps this firm would be likely to increase its borrowing from other lenders so that its borrowing portfolio would become more similar to its peer firms, even if its original lender remained healthy. Such a scenario could produce results like those in Table 5 even without any causal effect of lender distress. To test this hyposthesis, I performed a "placebo test" by running regressions similar to those in Table 5, but using a random selection of preperiod lenders instead of the list of distressed lenders. Coefficients on this random lender variable are still positive, but much smaller in magnitude and not statistically significant, indicating that this kind of mean reversion does not drive the results in Table 6. 
Table 6: Regressions illustrating counterfactual results if firms dependent on distressed lenders had not increased borrowing from non-distressed lenders

\begin{tabular}{lccccc} 
& $(1)$ & $(2)$ & $(3)$ & $(4)$ & $(5)$ \\
\cline { 2 - 6 } & -.068 & -.149 & -.102 & -.092 & -.084 \\
Pct. Financed by Distressed Lenders & $(.008)^{* * *}$ & $(.008)^{* * *}$ & $(.008)^{* * *}$ & $(.008)^{* * *}$ & $(.008)^{* * *}$ \\
Lender Diversity & .301 & .247 & .260 & .276 & .295 \\
& $(.035)^{* * *}$ & $(.039)^{* * *}$ & $(.038)^{* * *}$ & $(.035)^{* * *}$ & $(.035)^{* * *}$ \\
County $\times$ Size $\times$ Industry FE & Yes & Yes & Yes & Yes & Yes \\
Observations & 37789 & 37789 & 37789 & 37789 & 37789 \\
$R^{2}$ & .078 & .094 & .082 & .081 & .08 \\
\hline \hline
\end{tabular}

In column 1, the dependent variable is the ratio of the number of machines financed between 2008q3 and $2011 \mathrm{q} 2$ to the number financed between 2005q3 and 2008q2, just as in the baseline results in Table 3 .

In column 2 , the numerator of the dependent variable for firms with any preperiod machines from distressed lenders excludes any postperiod machines financed through non-distressed lenders in excess of the number of preperiod machines financed through non-distressed lenders.

Column 3 performs the same exercise for captive finance companies.

Column 4 performs the same exercise for non-distressed banks.

Column 5 performs the same exercise for other non-distressed finance companies.

Independent variables refer to precrisis firm characteristics. Standard errors (in parentheses) are clustered by modal preperiod lender.

Although the distressed lender coefficients in columns 3 to 5 are not statistically different from each other (or from zero), the largest coefficient is that in column 3, for captive finance finance companies. Thus, the data suggest that the captive finance companies played the largest role in servicing borrowers that had previously depended on lenders that became distressed.

Table 6 presents results that illustrate the importance of this substitution for the baseline results presented earlier. Column 1 of the table essentially replicates column 5 of Table 3, but Citigroup and the other distressed lenders are lumped together into a single variable. Column 2 then presents a similar result under the counterfactual assumption that firms doing any preperiod borrowing from the distressed lenders were unable to increase their borrowing from any non-distressed lenders in the postperiod. That is, for firms that had any preperiod machines financed through distressed lenders, the numerator of the dependent variable in column 2 excludes any postperiod machines financed through non-distressed lenders in excess of the number of preperiod machines financed through non-distressed lenders. Thus the 
coefficient in column 2 illustrates what the baseline result in column 1 would look like if the distressed-lender-dependent firms had not been able to increase their financing from other lenders.

Results from this exercise are striking. The coefficent estimate in column 2 is more than twice as large as that in column 1 . Where baseline results indicate that fully distressedlender-dependent firms invested about 30\% less than comparable firms after the crisis, the counterfactual in column 2 suggests they would have invested almost $75 \%$ less if they had been unable to increase their financing from other lenders. ${ }^{28}$

Thus, it appears that subsititution to other lenders played a large role in mitigating declines in financing among firms that had previously borrowed from lenders that became distressed, although this substitution was not enough to prevent an overall decline in financing.

The rest of the columns in the table again provide information on the relative importance of different kinds of alternative lenders in mitigating declines in financing. Columns 3, 4, and 5 display results that shut off substitution toward captive finance companies, non-distressed banks, and other non-distressed finance companies in the same way that substitution to all non-distressed lenders was shut off in column 2. Again, it is the captive finance companies in column 3 that are most important, although the other groups also play a role.

\subsection{Implications for aggregate investment}

Baseline results suggest that firms that were $100 \%$ dependent on the distressed lenders on my list financed about 30\% less equipment after the crisis than observably similar firms that were dependent on average lenders. However, even these average lenders were likely forced to reduce their lending to a level below the one they would have achieved if the financial

\footnotetext{
${ }^{28}$ One might argue that this comparison overstates the importance of substitution as it allows firms that never had a relationship with a distressed lender to increase their financing from non-distressed lenders without limit, while not allowing any increase for firms that did have such a relationship. A similar exercise that allows no firms to increase their borrowing from non-distressed lenders would produce a figure of $50 \%$ instead of $75 \%$.
} 
Table 7: Regressions measuring gap between firms dependent on healthiest lenders and firms dependent on distressed lenders

\begin{tabular}{|c|c|c|c|}
\hline & $(1)$ & $\overline{(2)}$ & $(3)$ \\
\hline Pct. Financed by Healthiest Lenders & $\begin{array}{l}.06 \\
(.04)\end{array}$ & $\begin{array}{c}.04 \\
(.02)^{* *}\end{array}$ & $\begin{array}{c}.04 \\
(.02)^{* *}\end{array}$ \\
\hline Pct. Financed by Distressed Lenders & $\begin{array}{c}-.09 \\
(.02)^{* * *}\end{array}$ & $\begin{array}{c}-.04 \\
(.02)^{* * * *}\end{array}$ & $\begin{array}{c}-.05 \\
(.01)^{* * *}\end{array}$ \\
\hline Pct. Financed by Any Bank & & $\begin{array}{c}-.007 \\
(.02)\end{array}$ & $\begin{array}{c}.0004 \\
(.02)\end{array}$ \\
\hline Pct. Financed by Any Finance Co. & & $\begin{array}{l}.006 \\
(.02)\end{array}$ & $\begin{array}{c}-.001 \\
(.01)\end{array}$ \\
\hline Lender Diversity & & $\begin{array}{c}.28 \\
(.04)^{* * *}\end{array}$ & $\begin{array}{c}.30 \\
(.03)^{* * *}\end{array}$ \\
\hline Constant & $\begin{array}{c}.19 \\
(.01)^{* * *}\end{array}$ & $\begin{array}{c}.17 \\
(.02)^{* * *}\end{array}$ & $\begin{array}{c}.17 \\
(.01)^{* * *}\end{array}$ \\
\hline County, Size, and Industry FE & & Yes & Yes \\
\hline County $\times$ Size $\times$ Industry FE & & & Yes \\
\hline Observations & 37794 & 37794 & 37794 \\
\hline$R^{2}$ & .009 & .05 & .08 \\
\hline
\end{tabular}

The dependent variable is the ratio of the number of machines financed between 2008q3 and 2011q2 to the number financed between 2005q3 and 2008q2. Independent variables refer to precrisis firm characteristics. Column 3 includes county-industry-size fixed effects and interactions as in column 5 of Table 3. Standard errors (in parentheses) are clustered by modal preperiod lender.

crisis had not occurred. To attempt to assess the implications of the contraction in credit supply for aggregate investment, one must attempt to assess the impact of the crisis on the credit supplied by lenders throughout the distribution and not just at the very bottom where my "distressed" lenders fall. In this section of the paper, I describe a simple counterfactual simulation aimed at this objective.

First, I identify certain lenders that appear to be among the least distressed in the sample, so that I may use these lenders' borrowers as a counterfactual for all other firms in the sample. A priori, I suspected that captive finance companies of large, stable equipment manufacturers would have been likely to be little affected by the crisis, as these lenders would have had little direct exposure to real estate and could likely rely on their parent companies' funds if necessary. Indeed, in specifications like the ones just presented, I find positive coefficients 
on variables measuring firms' dependence on Deere and Company and Caterpillar. ${ }^{29}$ I also find similar results for Wells Fargo, which remained relatively healthy during the crisis when compared to other large banking organizations. Table 7 presents regression results of this form, lumping Deere, Caterpillar, and Wells Fargo into the "Healthiest Lenders" category, while Citigroup is again lumped with all of the other distressed lenders in the "Distressed Lender" category.

I then use the estimated coefficients from column 3 of the table (which again includes the full set of county-size-industry dummies and interactions) to predict an investment ratio for each firm under the counterfactual assumption that every firm was financed entirely by Deere, Caterpillar, or Wells Fargo and no firms were financed by the distressed lenders. I sum the total number of postperiod machines financed by all firms in the sample under this counterfactual assumption, and I compare this sum to the total number of machines predicted by the same specification without the counterfactual. This exercise reveals that variation across preperiod lenders can explain about a $17 \%$ decline in total machines financed in the postcrisis period, relative to a counterfactual where all firms financed all of their pre-crisis machines through one of these three least-distressed lenders.

The total decline in the number of machines appearing in the data from the pre to the postperiod is about $45 \%$. Thus the $17 \%$ decline that I attribute to the effects of credit supply accounts for a bit more than one third of the total decline in financing by the firms appearing in the sample. ${ }^{30}$

As the firms in the sample are small businesses that are already reliant on secured financing, we might expect them to be among the most financially constrained firms in the economy. Thus, one might expect that this paper's results might overestimate the importance of credit supply in driving the decline in investment in the rest of the economy. On

\footnotetext{
${ }^{29}$ That is, I ran regressions with right-hand-side variables like "Pct. Financed by Deere and Company" just as I did with Citigroup in the regressions presented in the text.

${ }^{30}$ Note that this comparison assumes a counterfactual of no change in the total number of machines financed in the absence of the crisis and recession. Under an alternative assumption that the number of machines would have grown, the $17 \%$ figure attributable to credit supply would account for a smaller share of the total decline.
} 
the other hand, one might also think that secured lending against homogenous equipment like construction and farm machinery would be among the least information sensitive forms of lending. For this reason, one might argue that these firms should be better able to substitute from one lender to another and that this paper's results underestimate the effect of credit supply elsewhere in the economy. Given these opposing arguments, one should likely be cautious in extrapolating the estimated effects from this paper to other sectors of the economy.

\section{Conclusions}

The Uniform Commercial Code governs the operation of a collateral registry system that allows secured lenders in the United States to publicly stake their secured claims in their borrowers' collateral. Although this system is an important piece of the plumbing of lending and investment in the United States, particularly for small businesses, it has been almost entirely ignored by researchers in economics and finance. This paper has used UCC filings to create a new dataset of equipment financing relationships, and it has used this dataset to evaluate the impact of lender distress on equipment financing during the recent crisis and recession.

Regression results indicate that firms dependent on the most distressed lenders reduced their equipment financing after the crisis by about $30 \%$ relative to average firms that did not depend on these distressed lenders, despite a considerable amount of substitution toward alternative lenders. Counterfactual simulations suggest that variation in distress across lenders can explain a $17 \%$ decline in the total number of machines financed after the crisis, or about one-third of the overall decline in machines financed by firms appearing in the sample. Although caveats remain, these results suggest that a contraction in credit supply caused a substantial part of the large decline in real investment seen during the recent crisis and recession. Nonetheless, other factors must still acount for the majority of the overall decline. 


\section{References}

Adam B. Ashcraft. Are banks really special? new evidence from the fdic-induced failure of healthy banks. The American Economic Review, 95(5):pp. 1712-1730, 2005.

Adam B. Ashcraft. New evidence on the lending channel. Journal of Money, Credit and Banking, 38(3), April 2006.

Ben S. Bernanke and Alan S. Blinder. Credit, money, and aggregate demand. The American Economic Review, 78(2):pp. 435-439, 1988.

Nicholas Bloom, Max Floetotto, and Nir Jaimovich. Really uncertain business cycles. Stanford University Working Paper, 2009.

Mark A. Carlson, Hui Shan, and Missaka Warusawitharana. Capital ratios and bank lending: A matched bank approach. FEDS Working Paper, (2011-34), July 2011.

Daniel R. Carvalho, Miguel A. Ferreira, and Pdero P. Matos. Lending relationships and the effect of bank distress: Evidence from the 2007-2009 financial crisis. Unpublished working paper, July 2012.

Sudheer Chava and Amiyatosh Purnanandam. The effect of banking crisis on bankdependent borrowers. Journal of Financial Economics, 99(1):pp. 116 - 135, 2011.

Xiaoqiang Cheng and Hans Degryse. Information sharing and credit rationing: Evidence from the introduction of a public credit registry. European Banking Center Discussion Paper, (2010-07S), February 2010.

Gabriel Chodorow-Reich. The employment effects of credit market disruptions: Firm-level evidence from the 2008-09 financial crisis. Unpublished working paper, October 2012.

Alain de Janvry, Craig McIntosh, and Elisabeth Sadoulet. The supply- and demand-side impacts of credit market information. Journal of Development Economics, 93(2):pp. 173 $-188,2010$. 
Simeon Djankov, Caralee McLiesh, and Andrei Shleifer. Private credit in 129 countries. Journal of Financial Economics, 84(2):pp. 299 - 329, 2007.

John C. Driscoll. Does bank lending affect output? evidence from the u.s. states. Journal of Monetary Economics, 51(3):pp. 451 - 471, 2004.

Ran Duchin, Oguzhan Ozbas, and Berk A. Sensoy. Costly external finance, corporate investment, and the subprime mortgage credit crisis. Journal of Financial Economics, 97 (3):pp. $418-435,2010$.

Roger Farmer. The stock market crash of 2008 caused the great recession: Theory and evidence. Working Paper 17479, National Bureau of Economic Research, October 2011.

Steven M. Fazzari, R. Glenn Hubbard, and Bruce C. Petersen. Financing constraints and corporate investment. Brookings Papers on Economic Activity, 1988(1):pp. 141-206, 1988.

Arturo Galindo and Margaret Miller. Can credit registries reduce credit contraints? empirical evidence on the role of credit registries in firm investment decisions. Annual Meetings of the Board of Governors, Inter-American Development Bank and Inter-American Investment Corporation, March 2001.

Jie Gan. The real effects of asset market bubbles: Loan- and firm-level evidence of a lending channel. The Review of Financial Studies, 20(6):pp. 1941-1973, 2007.

Robert E. Hall. Why does the economy fall to pieces after a financial crisis? The Journal of Economic Perspectives, 24(4):pp. 3-20, 2010.

Rainer Haselmann, Katharina Pistor, and Vikrant Vig. How law affects lending. Review of Financial Studies, 23(2):549-580, 2010.

Andrew Hertzberg, Jose Maria Liberti, and Daniel Paravisini. Public information and coordination: Evidence from a credit registry expansion. The Journal Of Finance, 66(2), 2011. 
R. Glenn Hubbard, Kenneth N. Kuttner, and Darius N. Palia. Are there bank effects in borrowers' costs of funds? evidence from a matched sample of borrowers and banks. The Journal of Business, 75(4):pp. 559-581, 2002.

Victoria Ivashina and David Scharfstein. Bank lending during the financial crisis of 2008. Journal of Financial Economics, 97(3):pp. 319 - 338, 2010.

Rajkamal Iyer, Samuel Lopes, Jose-Luis Peydro, and Antoinette Schoar. Interbank liquidity crunch and the firm credit crunch: Evidence from the 2007-2009 crisis. Unpublished working paper, June 2010.

Tullio Jappelli and Marco Pagano. Information sharing in credit markets: A survey. CSEF Working Paper, (36), March 2000.

Kathleen M. Kahle and Ren M. Stulz. Financial policies and the financial crisis: How important was the systemic credit contraction for industrial corporations? Working Paper 16310, National Bureau of Economic Research, August 2010.

Jarl G Kallberg and Gregory F Udell. The value of private sector business credit information sharing: The us case. Journal of Banking and Finance, 27(3):pp. 449 - 469, 2003.

Steven N. Kaplan and Luigi Zingales. Do investment-cash flow sensitivities provide useful measures of financing constraints? The Quarterly Journal of Economics, 112(1):169-215, 1997.

Anil K. Kashyap, Jeremy C. Stein, and David W. Wilcox. Monetary policy and credit conditions: Evidence from the composition of external finance. The American Economic Review, 83(1):pp. 78-98, 1993.

Asim Ijaz Khwaja and Atif Mian. Tracing the impact of bank liquidity shocks: Evidence from an emerging market. American Economic Review, 98(4):pp. 1413-42, 2008. 
Inessa Love and Nataliya Mylenko. Credit reporting and financing constraints. World Bank Policy Research Working Paper, (3142), October 2003.

Atif R. Mian and Amir Sufi. What explains high unemployment? The aggregate demand channel. NBER Working Paper Series, (17830), February 2012.

Casey B. Mulligan. Aggregate implications of labor market distortions: The recession of 2008-9 and beyond. NBER Working Paper Series, (15681), January 2010.

Marco Pagano and Tullio Jappelli. Information sharing in credit markets. The Journal of Finance, 48(5):pp. 1693-1718, 1993.

Damian Paletta and David Enrich. FDIC pushes purge at Citi. The Wall Street Journal, June 52009.

Daniel Paravisini. Local bank financial constraints and firm access to external finance. The Journal of Finance, 63(5):pp. 2161-2193, 2008.

Daniel Paravisini, Veronica Rappoport, Philipp Schnabl, and Daniel Wolfenzon. Dissecting the effect of credit supply on trade: Evidence from matched credit-export data. Working Paper 16975, National Bureau of Economic Research, April 2011.

Joe Peek and Eric S. Rosengren. Collateral damage: Effects of the japanese bank crisis on real activity in the united states. The American Economic Review, 90(1):pp. 30-45, 2000.

Manju Puri, Jrg Rocholl, and Sascha Steffen. Global retail lending in the aftermath of the us financial crisis: Distinguishing between supply and demand effects. Journal of Financial Economics, 100(3):pp. 556 - 578, 2011.

Rodney Ramcharan, Skander Van den Heuvel, and Stephane Verani. From wall street to main street: The impact of the financial crisis on consumer credit supply. Unpublished working paper, August 2012. 
Tara Rice and Jonathan Rose. When good investments go bad: The contraction in community bank lending after the 2008 gse takeover. Unpublished working paper, September 2010.

Philipp Schnabl. The international transmission of bank liquidity shocks: Evidence from an emerging market. The Journal of Finance, 67(3):897-932, 2012.

Myron B. Slovin, Marie E. Sushka, and John A. Polonchek. The value of bank durability: Borrowers as bank stakeholders. The Journal of Finance, 48(1):pp. 247-266, 1993.

Bradford Stone and Kristen David Adams. Uniform Commercial Code in a Nutshell, rth. West Publishing Co., St. Paul, MN, 2008. 